\title{
Balanophora subcupularis P. C. Tam (Balanophoraceae): New Record Species for Flora of Vietnam
}

\author{
Nguyen Thanh Tung ${ }^{1 *}$, Nguyen Viet Than ${ }^{1}$ and Nguyen Quang Hung ${ }^{2}$ \\ ${ }^{1}$ Department of Pharmacognosy, Ha Noi University of Pharmacy \\ ${ }^{2}$ Institute of ecology and biological resources, VietNam academy of science and technology
}

"Corresponding author: Tung NT, Department of Pharmacognosy, Ha Noi University of Pharmacy, 13-15, Le Thanh Tong street, Hoan Kiem District, Ha Noi, Vietnam, Tel: +0975002607; E-mail: thanhtungng.pharmacist@gmail.com

Received date: Sep 15, 2017; Accepted date: Oct 12, 2017; Published date: Oct 16, 2017

Copyright: $\odot 2017$ Tung NT, et al. This is an open-access article distributed under the terms of the Creative Commons Attribution License, which permits unrestricted use, distribution, and reproduction in any medium, provided the original author and source are credited.

\begin{abstract}
Balanophora subcupularis P.C.Tam, a new record species from Nui Ba forest (Lam Dong prov., Vietnam), is described, illustrated and compared to some species in the same genus Balanophora, together with a species with similar morphological features. The results were database to identify the species of Balanophora subcupularis P.C.Tam.
\end{abstract}

Keywords: Balanophora subcupularis; Lam Dong prov;; Morphological features

\section{Introduction}

Genus Balanophora is a small genus which belongs to family Balanophoraceae. There were about 19 Balanophora species which mainly distributed in tropical Africa and Australia, temperate to tropical Asia, and the Pacific Islands. In Vietnam, there were records of 6 species of genus Balanophora. Species in genus Balanophora have some biological activities such as radical scavenging activity; inhibit HIV effects, hypoglucemic effects, analgesic effects and antiinflammatory effects [1-4].

In order to determine the number and distribution of Balanophora species in Lam Dong prov., an investigation was carried out in November 2016. In hill range of Nui Ba mountain (Lac Duong distr. Lam Dong prov.), wild population of Balanophora subcupularis P.C.Tam was discovered. This was a new record species for Flora of Vietnam. In this paper, the morphologic features of new record species was described and illustrated with pictures and drawing, compared to some species of the same genus with similar morphologic features.

\section{Discussion}

\section{Description}

Sample of Balanophora species was collected at Nui Ba forest (Lac Duong district, Lam Dong province, Vietnam) in November 2016.

\section{Scientific name}

Balanophora subcupularis P.C.Tam (Balanophoraceae)

\section{Morphologic features}

Herbs monoecious, yellowish brown rhizome unbranched or in a small mass, branches sub-globose, surface with granular warts and scattered yellow stellate lenticels. Scapes reddish, 3-7 cm. Leaves 5-8, spirally arranged, broadly ovate, apex obtuse. Elliptical inflorescences, 1-2 cm. Male flowers: at basal of androgynous inflorescences, nearly actinomorphic. Pedicel ca. $0.8 \mathrm{~mm}$. Perianth lobes usually 4 , widely ovate, apex truncate, less than $1.5 \mathrm{~mm}$. Spadicles subclavate, $1 / 2$ ellipsoid. Female flowers: yellowish, at basal of spadicles and main axis of inflorescences. Flowers in October to November.

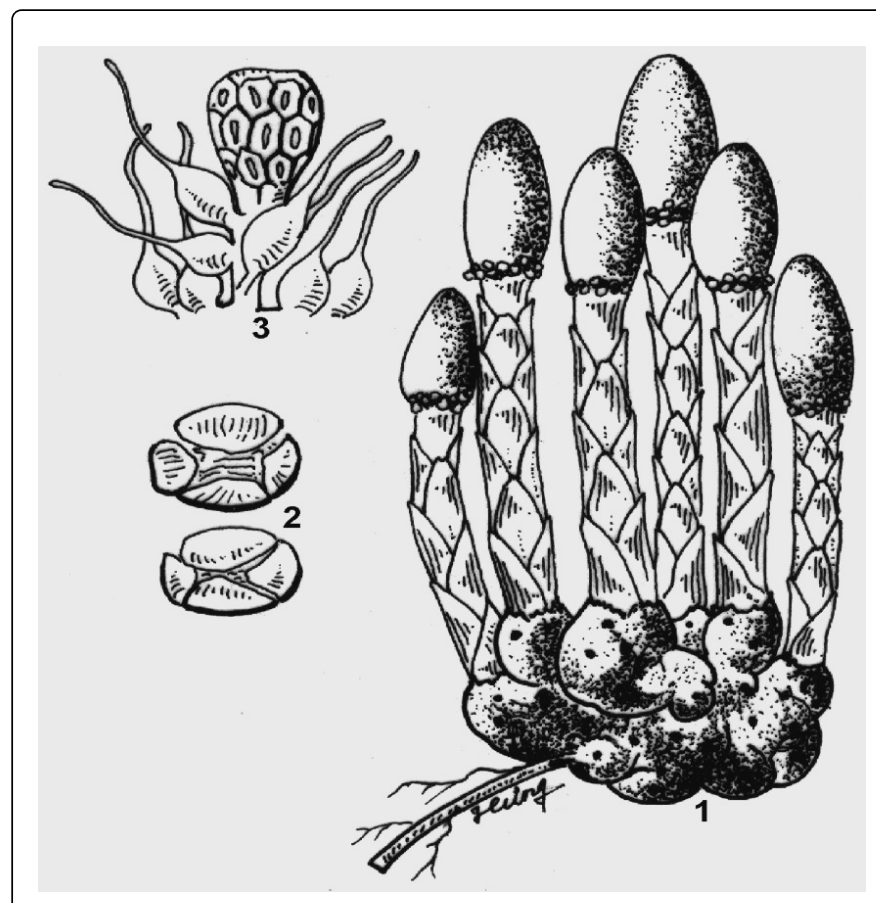

Figure 1: Drawing of Balanophora subcupularis P.C.Tam: 1. Plants; 2. Male flower; 3. Female flowes and spadicle. 
Citation: Tung NT, Than NV, Hung NQ (2017) Balanophora subcupularis P. C. Tam (Balanophoraceae): New Record Species for Flora of Vietnam. J Pharmacogn Nat Prod 3: 142. doi:10.4172/2472-0992.1000142

Page 2 of 3
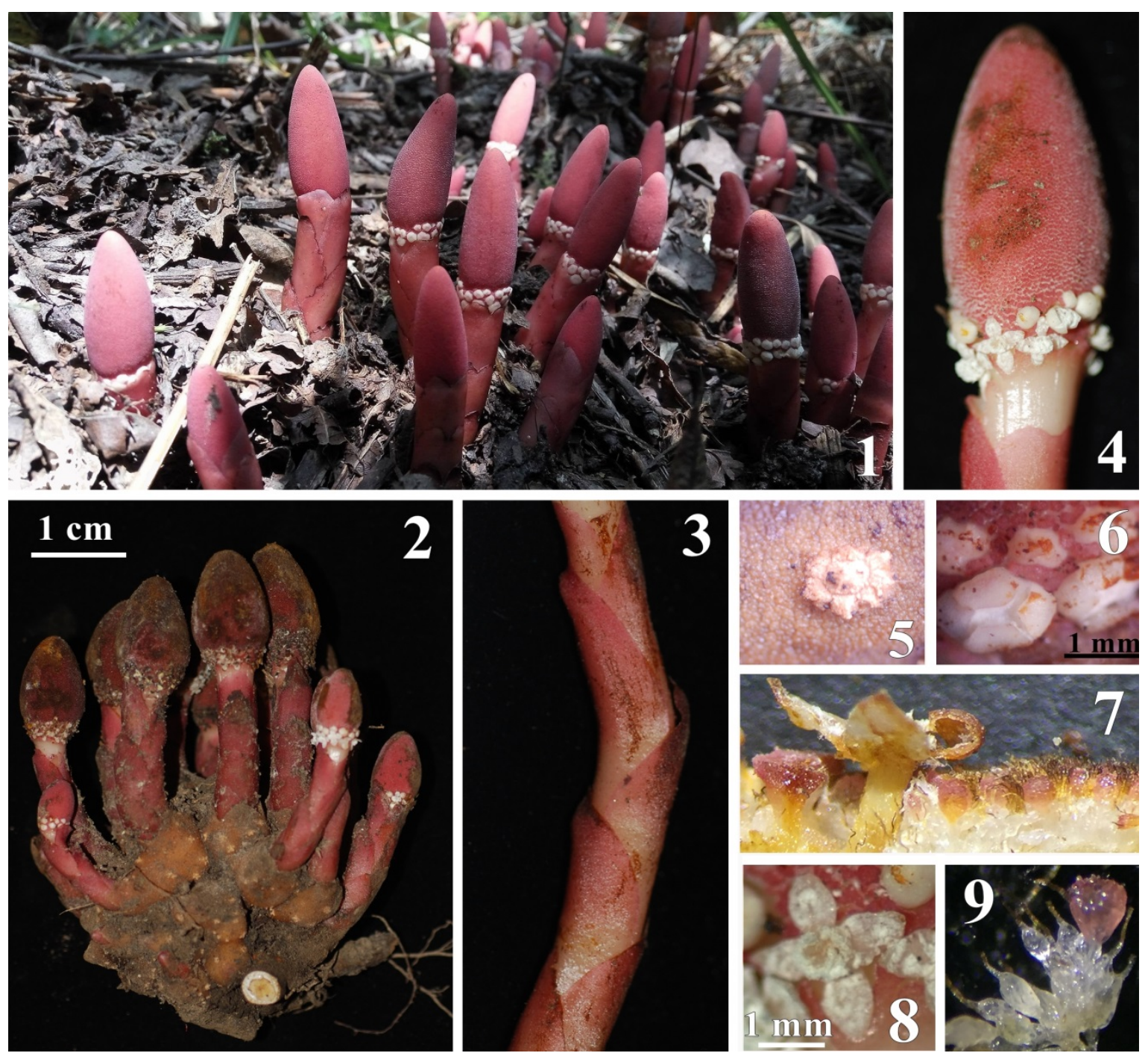

Figure 2: Morphologic features of Balanophora subcupularis P.C.Tam: 1. Habitat; 2. Flowering plant; 2. Scape with leaves; 4 . Andogynous inflorescences; 5. Rhizome surface with granular warts and scattered yellow stellate lenticels; 6,8. Male flowers; 7 . Vertical inflorescence; 9. Female flowers and spadicles.

\section{Distribution and habitat}

The samples of Balanophora subcupularis was found in Nui Nui Ba forest which is located in Lac Duong district of Lam Dong province, Vietnam at altitudes of about $1500 \mathrm{~m}$. In the world, this species was found in China (Guangdong, Guangxi, Guizhou, Jiangxi, Hunan, Yunnan), Myanmar and Japan [1-3].

\section{Conclusion}

\section{Conservation}

Balanophora subcupularis P.C.Tam was monoecious plant with male flowers basally on andogynous inflorescences. This characteristic was similar to some species of the same genus. Table 1 showed the comparison of some monoecious species of genus Balanophora.

\begin{tabular}{|c|c|c|c|c|}
\hline Features & B. subcupularis & B. fungosa & B. abbreviate & B. fargesii \\
\hline & $\begin{array}{l}\text { Yellowish } \\
\text { brown } \\
\text { rhizome. }\end{array}$ & $\begin{array}{l}\text { Yellowish } \\
\text { brown } \\
\text { rhizome. }\end{array}$ & $\begin{array}{l}\text { Plant creamy } \\
\text { white to } \\
\text { grayish }\end{array}$ & $\begin{array}{l}\text { Yellowish } \\
\text { brown } \\
\text { rhizome. }\end{array}$ \\
\hline Colour & $\begin{array}{l}\text { Scapes } \\
\text { reddish }\end{array}$ & $\begin{array}{l}\text { Scapes pink, } \\
\text { reddish } \\
\text { orange, or } \\
\text { occasionally } \\
\text { yellowish }\end{array}$ & & $\begin{array}{c}\text { Scapes } \\
\text { yellow to } \\
\text { orange }\end{array}$ \\
\hline Leaves & $\begin{array}{c}\text { leaves } 5-8, \\
\text { spirally } \\
\text { arranged }\end{array}$ & $\begin{array}{l}\text { leaves } 15-30, \\
\text { spirally } \\
\text { arranged or } \\
\text { rarely } \\
\text { opposite, } \\
\text { imbricate }\end{array}$ & $\begin{array}{l}\text { leaves } 4-7 \text {, } \\
\text { oblong to } \\
\text { ovate }\end{array}$ & $\begin{array}{l}\text { connate into } \\
\text { a single } \\
\text { sheathlike } \\
\text { whorl, } \\
\text { surrounding } \\
\text { middle of } \\
\text { scape }\end{array}$ \\
\hline
\end{tabular}


Citation: Tung NT, Than NV, Hung NQ (2017) Balanophora subcupularis P. C. Tam (Balanophoraceae): New Record Species for Flora of Vietnam. J Pharmacogn Nat Prod 3: 142. doi:10.4172/2472-0992.1000142

Page 3 of 3

\begin{tabular}{|c|c|c|c|c|}
\hline Inflorescences & ellipsoid & $\begin{array}{c}\text { ellipsoid, } \\
\text { ovoid, or } \\
\text { conically ovoid }\end{array}$ & $\begin{array}{c}\text { globose to } \\
\text { ellipsoid, apex } \\
\text { obtuse to } \\
\text { rounded }\end{array}$ & $\begin{array}{c}\text { ovoid to } \\
\text { subglobose }\end{array}$ \\
\hline $\begin{array}{c}\text { Male flowers } \\
\text { Perianth } \\
\text { lobes } \\
\text { of male } \\
\text { flowers }\end{array}$ & $\begin{array}{c}\text { nearly } \\
\text { actinomorphic } \\
\text { ovally 4, } \\
\text { ovidely apex } \\
\text { acute or } \\
\text { truncate }\end{array}$ & $\begin{array}{c}\text { actinomorphic } \\
\text { elliptic, apex } \\
\text { acute }\end{array}$ & $\begin{array}{c}\text { zygomorphic } \\
\text { imbricate, } \\
\text { rounded }\end{array}$ & $\begin{array}{c}\text { 3, broadly } \\
\text { deltoid }\end{array}$ \\
\hline $\begin{array}{c}\text { Female } \\
\text { flowers }\end{array}$ & $\begin{array}{c}\text { at basal of } \\
\text { main axis of } \\
\text { inflorescences }\end{array}$ & $\begin{array}{c}\text { at basal of } \\
\text { spadicles and } \\
\text { main axis of } \\
\text { inflorescence }\end{array}$ & $\begin{array}{c}\text { mostly on } \\
\text { basal stipe of } \\
\text { spadicles }\end{array}$ & $\begin{array}{c}\text { only on main } \\
\text { axis } \\
\text { of }\end{array}$ \\
\hline
\end{tabular}

\section{Acknowledments}

The authors wish to express their sincere gratitude to VAST for partial financial support (Project VAST.CTG.04/16-17).

\section{References}

1. Flora of China (2003) Vol 5, pp: 272-276.

2. Jin Murata (2016) Balanophora subcupularis (Balanophoraceae), New to Japan. J Jpn Bot. 91: 47-48.

3. Tanaka (2003) New or noteworthy plant collections from Myanmar (1). Hydrobryum japonicum, Balanophora subcupularis, Rhopalocnemis phalloides and Sonerila laeta. J Jpn Bot 81: 324-331.

4. Wang (2012) Phytochemicals and biological studies of plants from the genus Balanophora. Chemistry Central Journal 2012 6:79.

Table 1: Morphologic features comparison of some species of genus Balanophora. 